INTERNATIONAL JOURNAL OF RESEARCHES IN BIOSCIENCES, AGRICULTURE AND TECHNOLOGY

C VISHWASHANTI MULTIPURPOSE SOCIETY (Global Peace Multipurpose Society) R. No. MH-659/13(N) www.vmsindia.org

\title{
COMPARATIVE EFFECT OF GYPSUM, FYM AND PMC.ON YIELD OF GREENGRAM AND CHARACTERISTICS OF SODIC VERTISOLS
}

\author{
V. P. Babhulkar, P. R. Kadu and P. C. Pagar \\ College Of Agriculture, Nagpur- (M.S.) India \\ Deptt of Agril. Chemistry and Soil Science \\ Dr. Panjabrao Deshmukh Krishi Vidyapeeth, \\ Akola, Maharashtra- 444104
}

\section{ABSTRACT}

A field experiment was conducted to study the impact of gypsum with and without FYM and PMC on yield of greengram and dynamics of characteristics of Sodic Vertisols The soil had pHs 8.8, ECe 2.5, 4 dSm"1, SARe 16 , He $0.4 \mathrm{~mm} \mathrm{ha"}^{1}$ and $100 \%$ GK value $5 \mathrm{t} \mathrm{ha"1.} \mathrm{Significantly} \mathrm{highest} \mathrm{increased} \mathrm{in} \mathrm{grain} \mathrm{and} \mathrm{straw} \mathrm{yield} \mathrm{of}$ greengram by 85 and 55 per cent over control was noticed due to combined application of gypsum @ $50 \%$ GR and FYM $@ 5$ t ha" 1 and this gave maximum net monetary return and B:C ratio. This combination reduced pHs, ECe and SARe and increased HC of Sodic Vertisols over gypsum @ 50\% GR, FYM and PMC when given separately. A highly significant negative relationship of grain yield with pHs $(\mathrm{r}=-0.669)^{*}$, ECe $(\mathrm{i} \sim-0.805)^{* *}$ and SARe $(\mathrm{r}-0$ $843)^{* *}$ and positive with HC $(\mathrm{r}=0.860)^{* *}$ was registered. The model $\left.\mathrm{Y}=-23.80+-5.66^{*} \mathrm{pHs}-1.84 \mathrm{ECe}-0.97\right)^{* *}$ SARe $+8.03^{*} \mathrm{HC} . . . . ., \mathrm{R} 2-0.9408^{* *}$ was found to be best in predicting grain yield of green gram with $94 \%$ raviability.

Keywords: Green gram, sodic Vertisols (jypsum, FYM, PMC, grecngratn, xoi characteristics, relationship

\section{INTRODUCTION}

Amongst the various amendments, gypsum found to be superior in improving the alkali black clays as compared to other amendments (Sharma and GupUi, 1986) However, efVectivity of it, especially in Vertisols can be increased with (he addition of FYM by improving their hydraulic conductivity (Kalane el al., 1996) FYM predominantly consists of humic substances and expected to induce slow but steady improvement in structural stability by reducing the sodicity (Minhas, c( al., 1995). An attempt was made to study the impact of gypsum with and without FYM and PMC on productivity of greengram and changes in characteristics of sodic Vertisols developed on alluvium of basaltic origin in Purna valley of Vidarbha.

\section{MATERIAL AND METHODS}

A field trial in randomised block design was conducted on green gram (Kharif) grown in sodic Vertisols having pHs 8.8 , ECe $2.80 \mathrm{dSm}^{1}$, SARe $16 \mathrm{HC} 0.40 \mathrm{~cm} \mathrm{hr}^{1}$ and $100 \%$ OR value 5 $\mathrm{t}$ ha" 1 . The soil under test crop was very fine, montmorillontie, belongive to hyperthermic family of Sodic Vertisols. Treatments (seven) were i) Control (no gypsum) ii) gypsum @ 50\% OR (2.5 t ha'1 ) iii) gypsum @ 100 + G.R. (5 t ha'1 \} iv) FYM@5 t ha'1 , v) PMC @ 2.5 t ha"1 vi) Gypsum@50\% GR + FYM @ 5. t ha'1 vii) Gypsum fa). 50\% GR + FYM @ 2.5 t ha"1, Gypsum, FYM and PMC were applied before sowing of greengram, whereas recommended doses of fertilizers $20 \mathrm{~kg} \mathrm{~N}$ and $40 \mathrm{~kg} \mathrm{P} \mathrm{P}_{2} \mathrm{Os}$ ha"1 were applied at the time of sowing. Soil Characteristics were determined as per Richards (1954) and statistical analysis was done by following the procedure of Pause and Sukhatme( 1985).

\section{RESULTS AND DISCUSSION}

Yield of green gram : Data revealed that grain- and straw yields of greengram were increased significantly over control due to incorporation of gypsum, FYM or PMC each alone and in combinations (Table 1). An application of gypsum @ 50 and 100\% GR gave significantly higher grain and straw yields over control; but both the levels were at par with each other. Data further indicated that the combined addition of gypsum fa) 50\% GR either with FYM@5 or with PMC@ 2.5 t ha"1 improved the grain and straw yields However, significantly maximum increase in grain yield was recorded with the combination of gypsum@50\% GR + FYM@5 t ha"1, and this combination was fotind to be superior over the combination of gypsum @ 50\% GR + PMC @ 2.5 $\mathrm{t}$ ha" 1 , in respect of grain yield, whereas, both the combinations were at par in respect of straw yield Maximum net monetary returns and B:C ratio were also obtained due to combine application of gypsum @ 50\% GR + FYM@ 5 t ha"' and the increase was of the order of 85 and 55 per cent over control in respect of grain yield and straw yield respectively. 


\section{Soil Characteristics:}

Reduction in pHs, ECe andn SARe, and , improvement in $\mathrm{HC}$ were noticed due to addition of various amendments and their combinations (Table 2). An addition of gypsum ((i). 30 and 100\% GR decreased pHs, ECe and SARe and increased 11C significantly over control. Data furtb'-r reflect that the integration of gypsum ( $f>50 \% \mathrm{CiR}$ with FYM or PMC further reduced the salinity and sodicity of soil by improving $\mathrm{HC}$ as; compared to gypsum @ $50 \%$ GR or FYM or PMC alone. However, both these combinations had more or same effect pertaining to reducing the salinity and sodicity of soil. These observation corroborated with the results of Minhas (1995) Beneficial effect of gypsum, FYM and PMC in reducing the salinity / sodicity of soils can be related to its $\mathrm{Ca}$ content and mobilisation of native $\mathrm{Ca}$ from the soil.

\section{Relationship between yield and soil characteristics;}

A highly significant negative relationship of grain yield with salinity sodiciu characteristics i.e. pHs ( $\mathrm{r}=-0.669),{ }^{*}$ ECe $(\mathrm{r}=$ $0.805)^{* *}$ and SARe $(\mathrm{r}-\quad-0.843)^{* *}$ and positive relationship with $\mathrm{HC}(\mathrm{r}=0.860)$ were noticed. The detrimental effect of salinity and sodicity on yield of crops can be related to nutritional imbalance and restricted water availability to the plants as reported by Khandelwal and Lal (1991). Amongst the various yield contributing parameeters, soil moisture is the major factor especially in Vertisols contributing, to the productivity of crops and this is mainly governed by $\mathrm{HC}^{\prime}$ of soil (Blokuis, 1989) This has a negative relationship with $\mathrm{pHs}$ $(\mathrm{r}=-0.913)^{* *}$ ECe $(\mathrm{r}=-0.954)$ and SARe $(\mathrm{r}=$ $0.887)^{* *}$.

Regression equations based on single characteristics of soil are less reliable as the soil is a medium defined by various interactions among various soil characteristics and therefore, multiple linear regression models are developed on the basis of data obtained (Table 4) and the model No. 1 i.e. $\mathrm{Y}=-23.80+5.66^{*} \mathrm{pHs}$ - 1.84 ECe 0917** SAR I 8.03* HCR ${ }^{2}-0.9408^{* *}$ was found to be best (based on ' $\mathrm{R}^{2}$ ' value) in predicting grain yield of green gram with 94per cent variability. This model is best as the " $\mathrm{R}^{2}$ ' value of it is highly significant and partial regression coefficients of most of the variables in this model fond significant either at 1 or $5 \%$ level.

Table 1 : Effect of various amendments on yield of green gram

\begin{tabular}{|c|c|c|c|c|}
\hline \multirow[t]{2}{*}{ Treatments } & \multicolumn{2}{|c|}{ Yield q ha-1 } & \multirow{2}{*}{$\begin{array}{c}\text { Net monetary returns } \\
\left(\text { Rs. ha- }{ }^{-1}\right)\end{array}$} & \multirow{2}{*}{$\begin{array}{c}\text { B.C. } \\
\text { Ratios }\end{array}$} \\
\hline & Grain & Straw & & \\
\hline Control & 8.27 & 16.18 & 9,455 & 2.44 \\
\hline $\begin{array}{l}\text { Gyp @ } 50 \% \text { GR } \\
\left(2.5 \mathrm{t} \mathrm{ha}^{-1}\right)\end{array}$ & 11.81 & 23.52 & 13,136 & 2.68 \\
\hline $\begin{array}{l}\text { Gyp @100\% GR } \\
\left(5 \mathrm{t} \mathrm{ha}^{-1}\right)\end{array}$ & 11.84 & 24.13 & 10,628 & 20.2 \\
\hline FYM $5 \mathrm{t} \mathrm{ha}^{-1}$ & 10.79 & 20.17 & 11,902 & 2.68 \\
\hline PMC $2.5 \mathrm{t} \mathrm{ha}^{-1}$ & 10.82 & 21.34 & 12,984 & 3.10 \\
\hline GYP @50\% GR +FYM & 15.35 & 25.03 & 17,890 & 2.89 \\
\hline Gyp @ $50 \%$ GR + PMC & 13.54 & 26.85 & 15,189 & 2.72 \\
\hline $\mathrm{CD}$ at $5 \%$ & 0.99 & 02.08 & - & - \\
\hline
\end{tabular}

Table 2 : Effect of various amendments on $\mathrm{pHs}, \mathrm{ECe},\left(\mathrm{dSm}^{-1}\right)$ SARe and $\mathrm{HC}\left(\mathrm{mm} \mathrm{hr}^{-1}\right)$ of soil

\begin{tabular}{|c|c|c|c|c|}
\hline \multirow{2}{*}{ Treatments } & \multicolumn{2}{|c|}{ Yield q ha-1 } & \multirow{2}{*}{$\begin{array}{l}\text { Net monetary returns } \\
\left(\text { Rs. ha }{ }^{-1}\right)\end{array}$} & \multirow{2}{*}{$\begin{array}{l}\text { B.C. } \\
\text { Ratios }\end{array}$} \\
\hline & Grain & Straw & & \\
\hline Control & 8.27 & 2.50 & 15.00 & 0.42 \\
\hline $\begin{array}{l}\text { Gyp@ @50\% GR } \\
\left(2.5 \mathrm{t} \mathrm{ha}^{-1}\right)\end{array}$ & 7.86 & 2.10 & 12.00 & 076 \\
\hline $\begin{array}{l}\text { Gyp@100\% GR } \\
\left(5 \mathrm{t} \mathrm{ha}^{-1}\right)\end{array}$ & 7.45 & 1.95 & 10.00 & 0.81 \\
\hline FYM 5 t ha-1 $^{-1}$ & 8.10 & 2.30 & 12.50 & 0.64 \\
\hline PMC $2.5 \mathrm{t} \mathrm{ha}^{-1}$ & 7.95 & 2.20 & 13.70 & 0.71 \\
\hline GYP @ $50 \%$ GR +FYM & 7.60 & 1.90 & 8.70 & .84 \\
\hline Gyp @ $50 \%$ GR + PMC & 7.50 & 1.75 & 9.30 & 0.87 \\
\hline $\mathrm{CD}$ at $5 \%$ & 0.15 & 0.18 & 1.10 & 0.20 \\
\hline
\end{tabular}

Table 3 : Multiple Liner regression equations

\begin{tabular}{|c|l|c|}
\hline Models & \multicolumn{1}{|c|}{ MLR } & R2 \\
\hline I & $\mathrm{Y}-23.80+5.664^{*} \mathrm{pH}-1.84 \mathrm{ECe}-0.917^{* *} \mathrm{SAR}+8.03^{*} \mathrm{HC}$ & $R^{2}=0.9408^{* *}$ \\
\hline II & $\mathrm{Y}=23.17+5.108^{*}-0.961^{*} \mathrm{SAR}+9.324^{*} \mathrm{HC} \ldots$ & $R^{2}=0.9390^{* *}$ \\
\hline III & $\mathrm{Y}-15.93-0.630^{*} \mathrm{SAR}+4.356 \mathrm{HC} \ldots$ & $\mathrm{R} 2-0.8807^{* *}$ \\
\hline IV & $\mathrm{Y}-22.02+0.88^{*} \mathrm{SAR} .$. & $\mathrm{R} 2-0.8615^{* *}$ \\
\hline
\end{tabular}

